\title{
The Works and the Mystery of Salvation in the Book of Revelation. A New Contribution to an Old Polemic
}

\author{
DANIEL MiHOC
}

Five hundred years ago, in troubling theological and spiritual developments of the Roman Church, Martin Luther critically approached its teaching about the soteriological value of works. The result of his inquiry was the famous sola fide doctrine. However he did not ignore the issue of works and tried repeatedly to explain their relationship with the faith. But, unfortunately, he did not consider the important contributions of the Epistle of St James and of St John's Revelation. In the introduction to the Apocalypse he expressed the possibility that he was missing "more than one thing in this book". His intuition was right. The book of Revelation conceals many mysteries, but first of all that of salvation. It speaks a lot about Christ and His salvific work, but also about the works of the faithful. In fact, the mystery of salvation is closely related to works. They play a crucial role in the preparation of the wedding of the Lamb with His bride. The accomplishment of God's plan depends on them. The judgment will be done according to the works. Therefore, a lot of onceignored things stand before us. Have they the potential to bring more light on the much-disputed relationship between faith and works?

Keywords: Apocalypse, Christ, works, faith, sola fide, mystery of salvation, divinization

\section{The problem}

The anniversary of 500 years from the beginning of the Reform offers a good occasion to evaluate both the achievements and the problems which resulted during such a long time of controversies, conflicts and, lately, dialogue. The old polemic times are far away, but the divisions are still contemporary realities. As we know, the Roman-Catholic monk Martin Luther had no intention to create an alternative Christian community, but to get positive reaction to the problems he was putting into light. As the evolution of things did not meet the expectations, a break-out followed with the known consequences.

One of the things Martin Luther could not accept was the practice of indulgences and the theological argumentation behind it. He understood that neither the Scripture nor the Tradition provide any support for such a doctrine. Studying the Pauline writings he was fascinated by the emphasis

* Daniel Mihoc, PhD Assistant Professor at the Andrei Șaguna Faculty of Orthodox Theology, Lucian Blaga University of Sibiu, Romania. Address: Str. Duiliu Marcu nr. 60, Cisnădie, Sibiu, RO-555300; e-mail:dmihoc@gmail.com. 
of faith he found there. Given the context, he tried to establish a correct teaching having in mind the necessity to reject from a solid basis the doctrine with which he was unhappy. This effort drove him to the famous sola fide, which till today constitutes a basic doctrine of all denominations which were a result of the stream of the Reform. For Martin Luther this was so vital that, when translating Romans 3.28, he added the adverb "allein" (only; sola, in Latin), which has no correspondent in the Greek text, to the substantive Glaube (faith; fide, in Latin) Let us have a look at the Greek text and at Martin Luther's 1522 German translation.

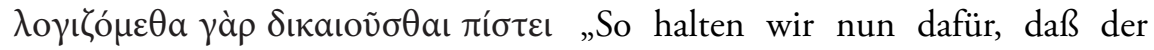

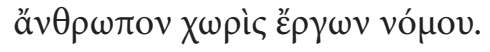
Mensch gerecht werde ohne des Gesetzes Werke, allein durch den Glauben.”

Martin Luther was convinced that he did not change the meaning of the original by introducing the adverb "allein" in his translation, but rather that it was requested by the text and its context, thus having a compulsory explanatory value.

This apparently little thing was the peak of a huge iceberg with important theological consequences. The Roman-Catholic answer which came with the Contra-Reform did not open any door to conciliation, but rather tried to clarify and to better establish the previous position. Neither have the recent evolutions brought significant development on this topic. Let us have a look on the most recent Roman-Catholic catechism, where we can read,

"An indulgence is a remission before God of the temporal punishment due to sins whose guilt has already been forgiven, which the faithful Christian who is duly disposed gains under certain prescribed conditions through the action of the Church which, as the minister of redemption, dispenses and applies with authority the treasury of the satisfactions of Christ and the saints." [quotation from Pope Paul VI's apostolic constitution Indulgentiarum doctrina, Norm 1]

"An indulgence is partial or plenary according as it removes either part or all of the temporal punishment due to sin." [quotation from Pope Paul VI's apostolic constitution Indulgentiarum doctrina, Norm 2]. Indulgences may be applied to the living or the dead. ${ }^{1}$

As for Martin Luther, with the time, attentive to the danger to be labeled antinomist, he nuanced his teaching. In the commentary on Galatians (published in 1535) he expressed a balanced view on the Law, recommending

1 Catechism of the Catholic Church, http://www.vatican.va/archive/ENG0015/_P4G. HTM\#\$1Q9, viewed on $7^{\text {th }}$ August 2017. 
"the royal road, so that we neither reject the Law altogether nor attribute more to it than we should".

During the Lutheran-Orthodox Dialogue the issue of salvation got special attention and each part had the opportunity to clarify its understanding. One of the documents resulting from this effort is "Understanding of Salvation in the Light of the Ecumenical Councils," ${ }^{3}$ issued by the 8th Joint Commission at the end of its meeting in Limassol, Cyprus, 1995. Acknowledging the different theological developments within the two communities of faith, the document points out the essential components of either of the two views on the same "mystery of salvation." The articles 8 and 9 include the most important statements for our topic. In order to facilitate a comparative study, we are quoting them face to face.

8. For the Orthodox Church, salvation is a gratuitous gift of God offered in Jesus Christ to all human beings (1 Tim. 2.4; Jn. 3.17), which they must both freely choose (Rev. 3.20) and work for (1 Cor. 3.13, 15.58; Phil. 2.12). According to St. Paul, this is synergia (1 Cor. 3.9; 2 Cor. 6.1). Once this gift of the divine grace is accepted by faith, Christ truly becomes the doctor of the souls and bodies of the faithful in the Holy Spirit, through the Word of God and the mysteries of the Church. He purifies their hearts (Ps. 50/51.10, Acts 15.9) and constantly renews their minds (Rom. 12.2; 2 Cor. 4.16), leading them from illumination/justification (2 Cor. 4.6) manifested by prayer in the heart (Rom. 8.26; keeping of the commandments (1 Jn. 3.22), to glorification (Jn. 17.22; 1 Cor. 12.26). The Orthodox Church does not hold that humanity
9. For Lutherans, justification is God's gracious declaration of the forgiveness of sins for the sake of Jesus Christ, crucified and risen, and at the same time the free gift of new life in him. Through the liturgical life, preaching, and sacraments of the Church, the Holy Spirit enables us to have faith in the gospel - that is, in God's gracious promise of forgiveness and new life. This promise is received by faith alone (sola fide); this means that salvation is by Christ alone, and not by any human works or merits. In faith Christians entrust themselves entirely to God's grace in Christ for salvation. In this way they enter a new relationship with God, as St. Paul says: "since we are justified by faith we have peace with God through our Lord Jesus Christ" (Rom. 5.1). Justification is a real participation in Christ, true God and true human being. In the Church,

2 Martin Luther, A Commentary on St. Paul's Epistle to the Galatians, translated by Theodore Graebner, Grand Rapids, Zondervan 1939, https://www.ccel.org/ccel/luther/galatians.txt, viewed on $8^{\text {th }}$ August 2017.

3 https://www.lutheranworld.org/sites/default/files/1995-Lutheran_Orthodox_DialogueEN.pdf, viewed on $7^{\text {th }}$ August 2017. 
inherited the guilt of the sin of Adam and Eve and is therefore worthy of eternal damnation, or that God chose from those thus guilty certain ones only to be saved without personal merit, or that Christ died on the Cross only for them, or that Christ loves only those sinners who are destined for heaven, or that God had to be reconciled to humanity by Christ's crucifixion. the believer by faith participates in Christ and all his gifts, and so has a share in the divine life. The presence of Christ in faith genuinely effects the righteousness of Christ in us, and leads believers to the sanctification of their lives. In this way, believers work out their salvation in fear and trembling, trusting that God in Christ is at work in them, both to will and to work for his good pleasure (Phil. 2.12-13).

One should notice the efforts of each part to answer the objection of the opposing one, and - important for our theme - the mentioning of a text from $\mathrm{St}$ John's Revelation in the Orthodox statement. Unfortunately, the two statements confirm once more the distance that still exists between the two traditions.

\section{Two disregarded writings}

The fact that Martin Luther was unhappy with two books from the canon of the New Testament, namely the Epistle of St James and St John's Revelation, is widely known. In the introductions to these books, he stressed some rationale behind his attitude.

In St James' statements about the works he saw an effort to dismantle the Pauline teaching on the role of the faith in salvation. That's why, probably overwhelmed by this darksome perspective, he characterized his writing as "an epistle of straw" ("Stroherne Epistel," in German). This attitude is in fact not justifiable. Today few Western theologians share the negative position of the one who is widely known as the Father of the Reform. Moreover, commentators are demonstrating that in fact there is no tension between $\mathrm{St}$ Paul and St James. One can go further to say that in fact there is no great distance between what St James really says and what Martin Luther understood about the role of works in a Christian's life. Being accused of antinomianism, he stressed that "Works are necessary for salvation but they do not cause salvation; for faith alone gives life." 5 And in his introduction to Romans, he argues that faith is

a living, creative and powerful thing". "Faith - he explains - cannot help doing good works constantly. It doesn't stop to ask if

\footnotetext{
4 Luther's Works, vol 35, St. Louis, Concordia 1963, p. 395; apud s.n., "Luther's Treatment of the 'Disputed Books' of the New Testament", http://www.bible-researcher.com/antilegomena.html, viewed on $7^{\text {th }}$ August 2017).

5 Ewald M. Plass (ed.), What Luther Says, St. Louis, Concordia 2006, p. 1509.
} 
good works ought to be done, but before anyone asks, it already has done them and continues to do them without ceasing. Anyone who does not do good works in this manner is an unbeliever... Thus, it is just as impossible to separate faith and works as it is to separate heat and light from fire! ${ }^{6}$

On the book of Revelation, Martin Luther expressed a quite similar attitude:

About this Book of the Revelation of John, I leave everyone free to hold his own opinions. [...] I say what I feel. I miss more than one thing in this book, and it makes me consider it to be neither apostolic nor prophetic. First and foremost, the apostles do not deal with visions, but prophesy in clear and plain words, as do Peter and Paul, and Christ in the gospel. For it befits the apostolic office to speak clearly of Christ and his deeds, without images and visions. [...] For myself, [...] I can in no way detect that the Holy Spirit produced it. [...] Many of the fathers also rejected this book a long time ago; although St. Jerome, to be sure, refers to it in exalted terms and says that it is above all praise and that there are as many mysteries in it as words ${ }^{7}$. Still, Jerome cannot prove this at all, and his praise at numerous places is too generous. Finally, let everyone think of it as his own spirit leads him. My spirit cannot accommodate itself to this book. For me this is reason enough not to think highly of it: Christ is neither taught nor known in it. But to teach Christ, this is the thing which an apostle is bound above all else to do; as Christ says in Acts 1[.8], "You shall be my witnesses." Therefore I stick to the books which present Christ to me clearly and purely."

\section{The reality: Christological and soteriological perspectives in the book of Revelation}

As one can easily notice, even at a cursory reading of the Book of Revelation, there is a huge gap between Martin Luther's view and reality. Christ is not

6 https://www.monergism.com/thethreshold/sdg/pdf/luther_prefaceromans.pdf, viewed on $7^{\text {th }}$ August 2017.

7 Martin Luther quotes freely from the St Jerome's Leter 53, To Paulinus (Ad Paulinum), bishop of Nola, AD 394. The Latin text reads as follows: "Apocalypsis Joannis tot habet sacramenta, quot verba. Parum dixi pro merito voluminis. Laus omnis inferior est: in verbis singulis multiplices latent intelligentiae." ("The Apocalypse of John has as many mysteries as words. In saying this I have said less than the book deserves. All praise of it is inadequate; manifold meanings lie hidden in its every word.") http://www.bible-researcher.com/jerome. html, viewed on $7^{\text {th }}$ August 2017.

8 Luther's Works, vol 35, p. 399; apud s.N., "Luther's Treatment", http://www.bible-researcher.com/antilegomena.html, viewed on $7^{\text {th }}$ August 2017. 
only "taught" in this book, but is intimately "known" by its author. The whole theological construct of the book is based on His revelation (ánокá $\lambda \nu \psi \iota \varsigma)$ made to the prophet John. Coming from Christ, it speaks primarily about Christ", as "what must soon take place" (Rev. 1.1) cannot be understood without the One to Whom has been given "all authority in Heaven and on earth" (Matt. 28.18; cf. Rev. 3.21; 5.5). Moreover, beyond this special act of revelation, the text witnesses the deep life "in Christ" ${ }^{10}$ of the author, his profound knowledge of the Old Testament as well as of the Church's Tradition. Special influence on his thought has the liturgical life of the Church. Worth noting here is the fact that the Liturgy ${ }^{11}$ is not just a source of his theology, but also an object of his teaching. The book stands as proof that he is deeply involved in the liturgical life of his Church not only as worshiper, but most probably as prophet, teacher, minister and hymnographer. All these aspects are inseparable from Christ as He is the both source and object of worship, of prophecy, of teaching and of every other ministry.

Usually for a Christian mind, Christ's name or image brings automatically the theme of salvation. The same happens in St John's Apocalypse. After a very special trinitarian greeting - at the end of which the martyric death of Christ, His resurrection and universal sovereignty are mentioned -, the prophet introduces the first Christological hymn,

To him who loves us and has freed / washed us from our sins

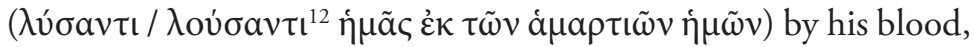

\footnotetext{
9 In fact the very first words suggests this double dimmension of the book: The greek ex-

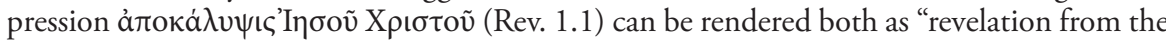
Christ" and "revelation about Jesus Christ."
}

10 Being himself a living example of what the Pauline expression $\mathcal{\varepsilon} v$ X $\rho ๘ \tau \tilde{\omega}$ (in Christ) means, throughout his book St John points out in various ways that this is the main characteristic of every Christian life.

11 When concerning the New Testament, we must not understand the terms "Liturgy" and "liturgical" merely as "cult" and "cultic", as they are widely used today. Fr. Alexander Schmemann points out that "in the early Church [...] the term 'leitourgia' was not a mere synonym of 'cult'. It was applied indeed to all those ministries and offices within the Church in which she manifested and fulfilled her nature and vocation; it had primarily ecclesiological and not cultic connotations". Alexander Schmemann, "Theology and Liturgy," in: idem, Church, World, Mission, Crestwood, St. Vladimir's Seminary Press 1979, p. 135-136.

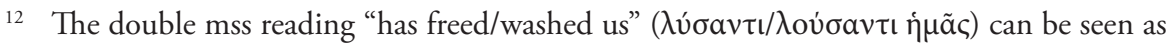
an expression of the rich and complex imagery of the book. Whatever would have been the original version, one must agree that both variants express the same soteriological reality. But the second term includes a blessed explanation through its allusion to the baptismal water. Andrew of Caesarea points out the multiple meaning by quoting both mss variants

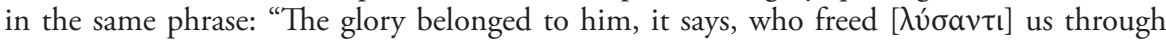

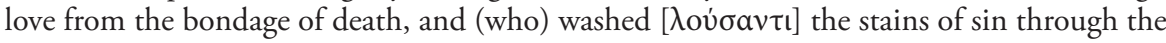
outpouring of his life-giving blood and water." Eugenia Scarvelis Constantinou, Andrew of 


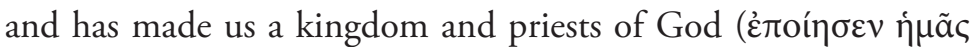

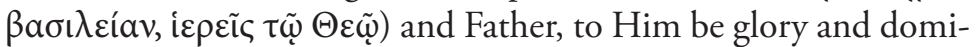
nion forever and ever! Amen. (1.5b-6).

The soteriological content of this text is clear from the very first lecture. Both the objective and the subjective salvation aspects are referred to. Knowing Martin Luther's special interest in soteriology and in stressing the universal priesthood, as well as his desire to argue his teachings biblically, it is difficult to explain why he was not able to grasp the value of such texts while he translated them. One explanation could be found in his attitude on the Epistle of St James. His negative stance toward it was dictated by the apparent opposition between St Paul's and St James' teaching on works. As the book of Revelation contains many more references to works than St James' epistle, this could be one more reason (alongside the ones mentioned in his introduction) behind his radical stance.

Going ahead in the book, we encounter a lot of Christology, ecclesiology and soteriology. Through prophetic-messages, descriptions of visions, allegoric narratives, hymns, St. John portrays Christ and His Church. The very first vision is Christological-ecclesiological: The Risen Christ is seen in the middle of His Church represented through the image of seven lampstands. The message of the image is very powerful and will be made crystal clear in the warning addressed to the Church in Ephesus: A community is Church as long as it is in communion with Christ, Who keeps it also in communion with the whole Christian community $(1.11-20 ; 2.5)$. This image brings us in the very core of the soteriology. As the first hymns quoted above pointed out, the goal of salvific work of Christ was to free= humans and to bring them up to His Kingdom. Once the salvific work is done and the Church is inaugurated, humans can enter in communion with Christ and participate in His Kingdom. But the entrance and the participation require action. The model is Christ Himself. For every Christian and for the Church as a whole. That's why St John portraits them (both the Church and the Christians) with reference to Christ.

The second Christological hymn speaks again about the salvific work

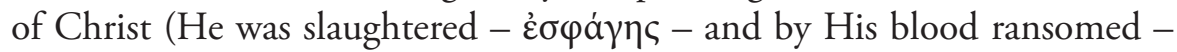

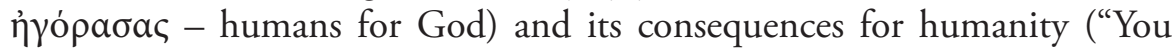
have made them" - i.e. the ones who He ransomed - "to be a kingdom and priests serving our God and they will reign on earth" - Rev. 5.9-10; NRSV).

Caesarea and the Apocalypse in the Ancient Church of the East, vol. 2, Québec, Université Laval

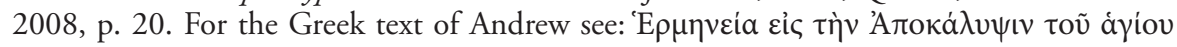

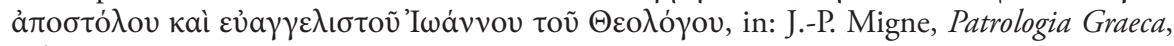
vol. 106, p. 225. 
Then, in the majestic vision of the Church of the seventh chapter, a very important specification is provided: The new status the humans who were made kingdom and priests are enjoying is not only the result of God's will and Christ's salvific work, but also the fruit of their own activity: Their robes are white (Rev. 7.9.13) because "they have washed their robes ( $\varepsilon " \pi \lambda v v a v$ tàs

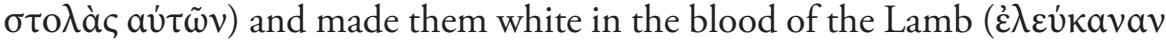

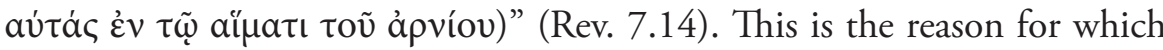
they can fulfill a priestly service: "For this reason - continues our text - they are before the throne of God, and worship Him day and night within His temple" (Rev. 7.15a; NRSV). The result of this faithful service will be the eternal and perfect communion with God: "The One sitting on the throne

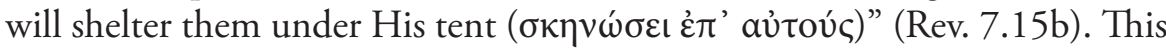
text is very important from a soteriological point of view because it provides the background for a correct understanding of the multiple 'works' statements of the book. It clearly mentions four stages of salvation:

(1) First, it speaks about the "blood of the Lamb", an image which encompasses the entire salvific ministry of Jesus Christ or what we technically call 'the objective salvation'. This is the central point of the theology of the Revelation. St John sees it as the turning point of history and the only foundation for every real human achievement.

(2) Second, it points out that Christians are not passive recipients of the fruits of Christ's salvific work. The active aorists "̋ँ $\pi \lambda v v a v$ ("they have washed") and غ̇ $\lambda \varepsilon v$ vavav ("they made [their robes] white") suggest knowledge, will and action. The image of washing is transparent to the sacrament of Baptism. Coming to the Baptism requires hearing of the Gospel, understanding and decision to die to the world with Christ in order participate in His life. As mentioned above, in the case of the first mention of the salvific work of Christ, the manuscript tradition offers two closely related soteriological perspectives: "He has freed ( $\lambda$ v́ $\sigma \nu \tau \iota)$ us from our sins" / "He has washed

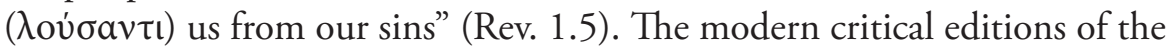
text prefer the first mentioned variant, but this option is purely subjective. ${ }^{13}$

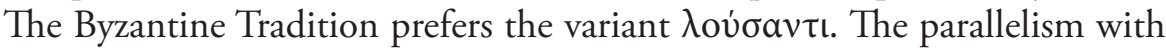
Rev. 7.14, as well as its double soteriological meaning (objective salvation and baptismal washing) suggest that most probably is the right one. Therefore, what Rev. 1.5 adds to the act of washing from Rev. 7.14 is that it is not merely a human praxis, but a synergic one. Christ Himself is acting through Baptism, washing the sins of the one who voluntarily comes to Him in order

13 Joseph Comblin, Le Christ dans l'Apocalypse, coll. Bibliothèque de Théologie. Théologie Biblique III 6, Tournai, Desclée 1965, p. 221, argues that it is impossible to decide which variant is the original one. 
to live a new heavenly life. The importance of this washing will be brought again into attention in the seventh beatitude of the book: "Blessed are those

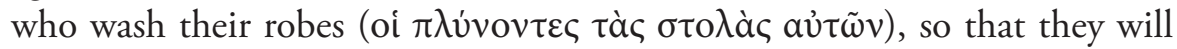
have the right to the tree of life and may enter the city by the gates" (22.14; NRSV).

(3) The 'washing of the robes in the blood of the Lamb enables people to stand "before the throne of God", "in His temple", and to worship Him continually (Rev. 7.15a). As we have already noted, two times before St John prepared us for this by telling (in two hymns) that one result/goal of Christ's sacrifice was the priesthood of the believers (Rev. 1.6; 5.10). St Peter names

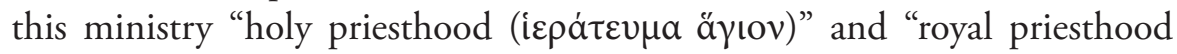

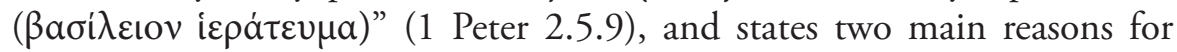
which it was given to the faithful: It enables them "to offer spiritual sacrifices acceptable to God through Jesus Christ (1 Peter 2.5) and to proclaim the Gospel to the world (1 Peter 2.9). The foundation and model of this ministry is Jesus Christ Himself: If $\mathrm{He}$, the Priest par excellence, brought Himself as sacrifice to the Father, as priests, the Christians are called to bring their own lives as sacrifice, serving Him ceaselessly, as their Lord did. The same ministry has in view St Paul when he exhorts the Romans "to present ( $\pi \alpha \rho \alpha \sigma \tau \tilde{\eta} \sigma \alpha \iota)$ " their "bodies as a living sacrifice, holy and acceptable

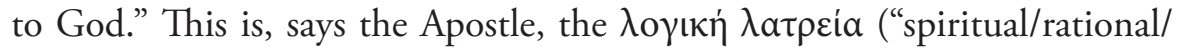
reasonable worship")"14 (Rom. 12.1).

(4) Finally, the ones consecrated priests, accomplishing their ministry properly, enjoy the full communion with God in His never-ending Kingdom (Rev. 7.15b-17; cf. 21.1-7; 22.14).

For study purposes, according to our text, we can classify these four stages into two groups: the ones which focus on Christ's/God's actions and the ones which focus on Christians actions. The first and the last fall into the first group, while the ones in the middle belong to the second. As our interest is to discover what the book of Revelation says about the Christians' calling to priesthood, its meaning and its relationship with works, we will focus on the middle group.

The above-mentioned texts about the hieratical dignity of the people of God had a huge influence in the Reform's rejection of the sacramental priesthood and the proclamation of exclusiveness of the universal one. In

\footnotetext{
14 The complexity of this Pauline expression puts in difficulty every translator/exegete. That is why the translations provide such a wide range of proposals. Some examples: "spiritual worship" (NRSV); "culte spirituel" (La Bible de Jérusalem; TOB 2010); "reasonable service" (American King James Version); "vernünftiger Gottesdienst” (Lutherbibel 1984); "true and proper worship" (NIV); "spiritual service of worship" (NASB).
} 
the Orthodox world they always were used for defining the meaning of the priesthood every baptized person is enabled to carry on, but their soteriological and pastoral value rarely has been exploited properly. ${ }^{15}$ Despite its place in the theological thought of the Protestant world, generally it plays no significant role in the communities of faith. On the contrary, in most cases they are extracted from their context and quoted in support of theses without considering properly the texts to which they belong. Both books, 1 Peter and Revelation, as well as their wider biblical context, provide us exactly what we need for a proper understanding of the implication of Christians' sacerdotal calling.

The sacerdotal perspective on the people of God compels us to pay special attention to the liturgical dimensions of the book. As we have noted above, the Apocalypse of St John contains a lot of liturgical images, hymns, prayers, terms. That is why it was considered "the most liturgical book of the New Testament." ${ }^{16}$ Indeed its content justifies such a view in the double meaning of the term: it includes constitutive things of the Christian worship and teaches what this means. Thus, this book not only mentions the sacerdotal ministry of all Christians, but also places it into its 'natural' background. This characteristic has a huge impact on the overall image of what it means and how can it be accomplished properly.

The theme of priesthood of all believers is closely related to everything St John says about Church and its members because it embraces every aspect of Christian life. This can be quite strange to the modern mind since most often it is used to sharply separate life into godly and secular. Unfortu-

15 One could see in this deliberate ignorance a form of reaction to the Reform's rejection of the sacramental priesthood and proclamation of the universal one as the unique Christian hieratical ministry.

16 Thomas F. Torrance, "Liturgie et Apocalypse," in: Verbum Caro XI (41/1957), p. 28.

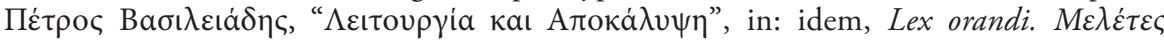

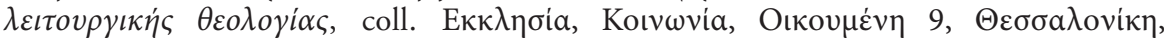

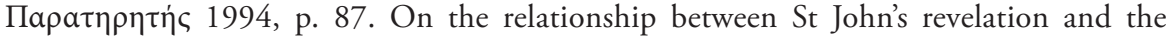
Church's worship see: Otto A. Piper, "The Apocalypse of John and the Liturgy of the Ancient Church," in: Church History 20 (1951), p. 10-12; Lucetta Mowry, "Revelation 4-5 and early Christian liturgical usage," in: Journal of Biblical Literature 71 (1952), p. 75-84; Gerhard Delling, "Zum gottesdienstlichen Stil der Johannes-Apocalypse," in: Novum Testamentum III (1959), p. 107-137. Massey H. Shepherd, The Paschal Liturgy and the Apocalypse, Richmond, Knox 1960; Panagiotis Bratsiotis, "L'Apocalypse de saint Jean dans le culte de l'Eglise grecque orthodoxe," in: Revue d'Histoire et de Philosophie Religieuses 42 (1962), p. 116-121; Pierre Prigent, Apocalypse et Liturgie, Cahiers Théologiques 52, Neuchâtel, Delachaux et Niestlé 1964; Leonard Thompson, "Cult and Eschatology in the

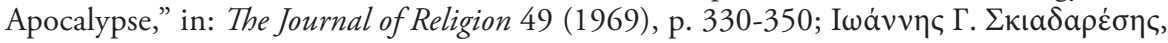

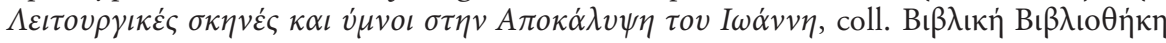

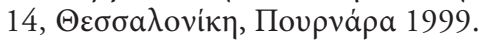


nately, often this is true for the contemporary Christians who, consciously or unconsciously, divide their time and acts into two quite distinct categories: one for those dedicated to God and another one for those dedicated to their worldly duties and physical needs. The book of Revelation stresses that what differentiates the Christian's life from her/his fellow's is its total dedication to God. The Christian is dead to the world and has been risen to an entirely new life in Christ (Rev. 20.4.6 ${ }^{17}$; cf. John 5.24-25). Therefore to conceive the Christian/spiritual life as parenthetical into a wide secular one is totally strange to the Gospel. But the problem it is not new at all. It was already present in New Testament Churches and we know about it because the inspired authors did everything necessary to combat such an ungodly understanding of what the new life in Christ means. For some, St John is more radical than the others, but if we compare, for instance, the Pauline

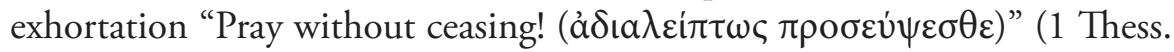
5.17) with the Johannine image of the Christians standing before the heavenly throne and worshiping God "day and night within His temple" (Rev. 7.9-10.15), we will conclude that both authors share the same view.

According to the mosaic Law, the priests could not perform their sacerdotal duties except in a state of ritual purity. As priests, in St John's Apocalypse the believers wear white robes, sign of purity. The whiteness of their robes is the first consequence of washing in the blood of the Lamb. The metaphor is of great importance for our theme. Its symbolism is very clear: the baptismal water purifies ${ }^{18}$. But this is not a guarantee that the 'whiteness' of the robes will last forever. In the Church of Sardis only a few Christians

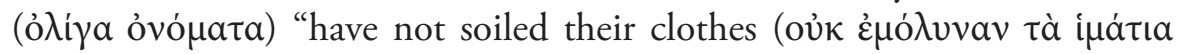

17 On the ecclesiological meaning of this text see Daniel Mihoc, "Împărăţia de o mie de ani," in: Anuarul Facultăţii de Teologie Andrei Şaguna Sibiu II (2001-2002), Sibiu, Ed. Universităţii "Lucian Blaga” 2002, p. 49-73.

18 Traditionally the neophytes were/are wearing white clothes, symbols of cleanness and holiness received by the grace of God. In the Holy Scripture and in the apocryphal literature the white color is the symbol of heaven, purity, holiness and salvation, W. Michaelis, " $\lambda \varepsilon v \kappa o ́ c "$, in: G. Kittel, G. Friedrich, Theological Dictionary of the New Testament, vol. 4, ed. and translated by G. W. Bromiley, Grand Rapids, Eerdmans 1967, p. 244 f. One being clothed in white means having a heavenly habit (Rev. 4.4; 6.11), a glorious one (2 Enoch 22.8f, 1 Enoch 62.15; Apocalypse of Peter 7f; Odes of Solomon 21,3). In some writings the white clothes are synonyms for the heavenly body of the saved ones. In 1 Enoch 62.15-16, for instance, we read about the clothes of the glory and of the life given by God; the ones who have received them will not age and their glory will not perish. According to The Ascension of Isaiah 9, 9, in the seventh heaven the saints receive heavenly clothes and are like the angels (2 Baruch 51.5). The idea possibly came from Dan 12.10 , where we read that in the times of tribulation the saints are "purified, made spotless and refined." 


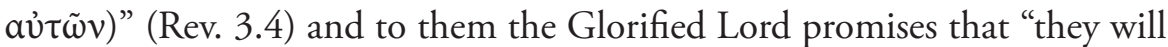
walk" with Him "dressed in white, for they are worthy" (Rev. 3.4). And immediately after He extends the promise to all who "conquer": every conqueror "will be clothed like them in white robes" (3.5). Now the soteriological meaning of the images of washing and white robes is clear and the context makes them crystal clear: each one by her/his works keeps the 'whiteness' of the clothes or soils them. Once soiled, if Christ gives time for repentance (as in case of Jezebel - Rev. 3.21), the same one can be cleaned again by washing in the same blood of the Lamb. And here, alongside faith, the works play a crucial role.

\section{A liturgical perspective}

In the Orthodox Liturgy, this understanding is pointed out again and again through an exhortation-calling to commit our whole life to Christ God: "Let us commit ourselves, and one another, and our whole life to Christ our God." 19 The importance of this commitment is stressed by its presence in each liturgical service of the Church, in most of them being repeated several times. Of particular significance are its occurrences in the Divine Liturgy, where it appears six times, the last one being preceded by an explanatory statement: "Having prayed for a perfect, holy, peaceful, and sinless day, let us commend ourselves and one another and our whole life to Christ our God." How this ideal can become reality in the lives of the faithful? The answer is both simple and complex: Knowing Christ's love, through which the faithful one was washed from the sins and became partaker in His kingdom and priesthood (Rev. 1.5), the Christian must not have any other desire than serving her/his Lord, knowing that there is no other way to real human accomplishment. But this goal does not just happen. It requires a stressing effort. First, prayer, as "every good and perfect gift is from above, coming down from the Father of the heavenly lights" (James 1.17). Prayer is the first act of worship the Christian-priests are to fulfill. Prayer itself is a work. It requires diligence, sacrifice, time, effort, ardor, true repentance and perseverance. Having requested God's help, the Christian begin $s^{20}$ and continues her/his day in a state of purity and holiness, as requires her/his status of human being consecrated to Him. Unfortunately, this remains merely an unattainable ideal for most Christians. The common experience tells us how easy

19 Available online: http://www.ocf.org/OrthodoxPage/liturgy/liturgy.html, viewed on $7^{\text {th }}$ August 2017.

20 The formulation of the prayer suggests that the Divine Liturgy was conceived to take place during the night or very early in the morning. This practice is still observed by many monastic communities and sometimes even in parishes. 
it is to fail at the very beginning or on the way. The crucial question is: how can this happen? Are we not the ones who were freed/washed by the blood of the Lamb? Are we not partakers of the "first resurrection" (Rev. 20.4.6) and priests to God? Is not our calling to live saintly - as purity is a sine qua non prerequisite for the priestly service we have to fulfill throughout our earthly lives? Indeed, all these are things which God wants to become realities in our lives. And not for their own sake but for our salvation. Because there is no other way to salvation than through identifying ourselves with our calling.

\section{The role of works}

As we have pointed out above, there is no tension between St Paul's and St James' teaching. But what would be the conclusion if we compare the Pauline soteriology with St John's? Do not the affirmations about the judgment

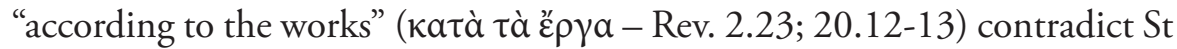
Paul's statements about the justification by faith? To answer this important question a thorough comparative investigation of the text of both authors should be done. The purpose of this article is not such an approach, but rather to investigate the "works" statements of St John in their context in order to offer a fresh perspective on his contribution to a better understanding of faith-works relationship in the process of salvation.

We have pointed out above the soteriological background against which we have to consider the ع́p $\gamma a$ statements of the book. One more thing is important for a proper understanding of their meaning and function within this writting: The book of Revelation is an expression of Christ's concern for His Church which is and will be confronted with new situations. The prophet is called to become Christ's messenger. He writes a pastoral epistle - because that is finally the book of Revelation ${ }^{21}$ - in which the parenetic genre meets the prophetic and the apocalyptic ones. And this characteristic is important in order to avoid the trap into which many have fallen. St John anticipate that it will be read in every Church and that the message will be heard - not necessarily understood, as the seven times repeated exhortation "Let anyone who has an ear listen to what the Spirit says to the Churches" (2.7.11.17.29; 3.6.13.22; NRSV) - by all the faithful gathered in liturgical assembly. As the seven letters point out, pneumatically there is a great variety among them, from spotless followers of the Lamb to some who are spiritually dead. Against this reality, the first benediction gets a special force: "blessed"

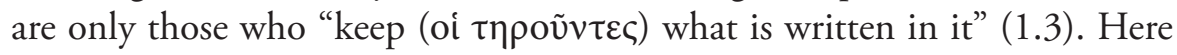

${ }^{21}$ Eugene Boring, Revelation, coll. Interpretation. A Bible Commentary for Teaching and Preaching, Louisville, John Knox Press 1989, p. 5. 


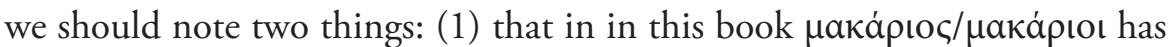
a soteriological meaning, being used for those who inherit the kingdom; and (2) that the verb $\tau \eta \rho \dot{\varepsilon} \omega$ is connected with the positive and active response of humans to the commandments of God. There is no other way of remaining in communion with God than by keeping His commandments.

This is the context in which the multitude of 'works' passages appear. The book mentions good works and bad works. The Glorified Christ is very concerned about works of His servants. They are called to fully participate in the new life into which He had introduced them. But fellowship with the Lord requires total dedication and obeisance to Him. Throughout the book, and especially in the seven prophetical messages, He is portrayed as the prototype of the Church and of every Christian. Himself has an earthly history which included obeisance to the will of the Father, faithful witness, confrontation with the satanic and worldly powers and martyred death. His victorious path constitutes both the fundament and the model of the Church. The Church itself follows His path and the same is happening in the case of each victorious Christian. The one Who loves His servants (Rev. 1.4) calls everyone to follow Him faithfully to the end, even if that means a martyred death (Rev. 2.10). The deeds play a special role in this process. The seven Churches present a very complex image from this point of view. There are good deeds, lack of good deeds and bad deeds. Some are praised for their works, as happens in the cases of the Churches in Ephesus (2.2-3), Thyatira (2.19) and Philadelphia (3.8). Some others are rebuked for the lack of good deeds, as happens in the Church of Sardis (3.2). Bad works are also mentioned, but they have no place in the Church of Christ. He appreciates the Church in Ephesus for hating the works the Nicolaitans, stressing that this is also His stance (2.6), and warns that He will kill the ones following the teaching of the false-prophetess Jezebel it they do not repent for their works (2.22).

The works are so important that upon them depends the very Christian status of a person/community. This happens in the case of the Church in Ephesus, which is commended for its works and is rebuked for the lack of others which used to be done but are no more present (2.4-5). In the case of the Church of Thiatira the Risen Christ sees a progress in works: "... your last words are greater than the first" (and stresses that this status must be preserved: "Hold fast what you have" (i.e. the works). The works of the Christians in Sardis seem to be empty and drive to the spiritual death (3.12). Seemingly the same happens in Laodicea (3.14f.). Totally different is the situation in Philadelphia, where exactly the work of confession enables the reciprocity expressed in Matt. 10.32: Christ will confess (witness) before His 
Father everyone who confesses Him before men. The image points to the Final Judgment where everyone will be judged according to her/his works

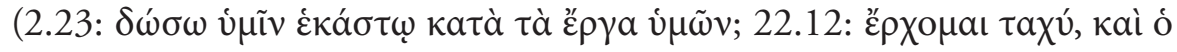

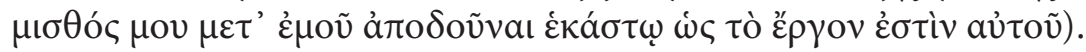

\section{The meaning of works}

In the book of Revelation the most used image for the accomplishment of the salvation process is that of the victory. Jesus Christ has conquered (Rev. 5.5) and that's why He can sit on the throne of the Father; His followers must conquer and thus will be granted the same privilege: "To the one who conquers I will give to sit on My throne as I have conquered and sat down with My Father on His throne" (3.21). Thus, the motif of conquering connects Christ's works with the Christians' works. But if what Christ's work meant and means is quite clear, can we say the same about what St John understands by the works of the Christians? Does he mean simply what we generally understand by 'good works' or there is something different? Fortunately, the book itself provides us some clues.

\subsection{The works embrace everything people are doing; they tell what} somebody really is. The first 'works' images occur in the first prophetic message to the Churches (2.1-7). First, here the works are connected with

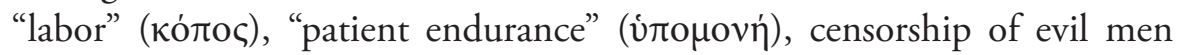

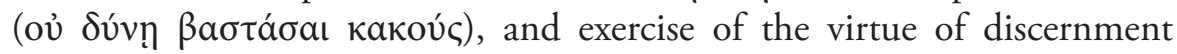

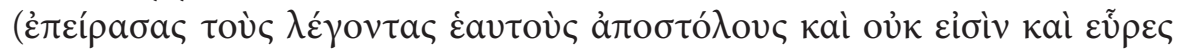
aủtoù $\zeta \varepsilon v \delta \varepsilon i ٓ \varsigma)$. In one word, it embraces a lot of virtues this community was acquired and was working out. But works do not stand alone; they require first of all love. Without true love works are not working and therefore become irrelevant, as have become the ones of the Church in Ephesus. More on this issue will be said below, in the section dedicated to the missionary relevance of the works.

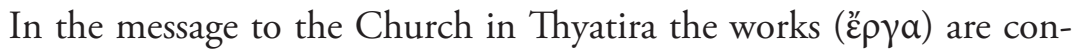

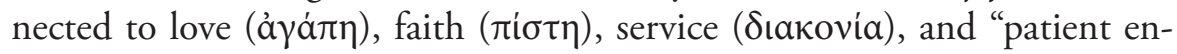

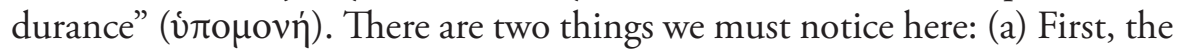
connection of the works with faith. St John does not speak a lot about faith, but the few references are enough to see his understanding. Jesus Christ is the model of faith; He is the faithful par excellence. The martyr Antipas, witnessing his faith with his blood, becomes also a paradigmatic example of what faith means. That is why Christ uses for him the same title the Church is using for Himself: ó $\mu a ́ p \tau v \varsigma$ ó $\pi ı \sigma \tau o ́ \varsigma /$. The true Christians are those who have the faith of Jesus (14.12), who do not deny their faith $(2.13 ; 3.8)$, even 
when their lives are at risk $(3.10 ; 13.10)$. (b) Contrary to what happens in Ephesus, here Christ sees a progress: "I know that your last works are greater than the first" (2.19; NRSV).

The works of the Church in Philadelphia are appreciated for their correspondence to the commandments of Christ (3.10). As in the case of the Church in Smyrna (2.9-10), here the works through which their faith is expressed put the Christians in conflict with the surrounding world. Even if this will sharpen the conflictual situation, they must persevere in these works and not search compromising formulas, as the Nicolaitans ${ }^{22}$ (2.6.15) or the followers of Jezebel (2.20-24). These heretical groups demonstrate that there are no really good works without true faith.

6.2 The works have missionary relevance. The Church in Ephesus is considered also from another perspective. It has lost the love it had at first. Therefore some of its works are not of the same quality they used to be. And this issue is so serious that the very Christian identity of this community depends upon recovering it. In this case, recovery means remembering the status from which it has fallen ( $\mu \nu \eta \mu o ́ v \varepsilon v \varepsilon \ldots)$, repentance ( $\mu \varepsilon \tau \alpha v o ́ \eta \sigma o v)$

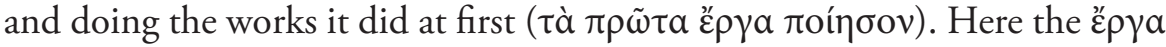
are related to the love. The first hymn of the book begins by mentioning the

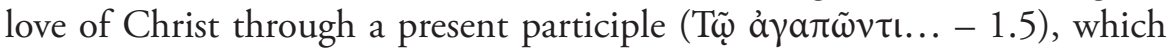
points out that it stands at the foundation of everything the Lord has done and is doing for the Church. Love towards God and neighbor stands also in the core of the Law and the Gospel. But here the context provides us a more specific direction ${ }^{23}$. The Churches are portraited as lampstands and this suggest light and so the image echoes the calling of Jesus' followers to be "the light of the world" (Matt. 5.14). Therefore the works have missionary value, as in Matt. 5.16. The loss of ardent love of God is manifested in a decreasing quality of the works and that does not bring the expected missionary results. In God's plan, the Gospel cannot reach the margins of the earth without the participation of Christ's disciples.

22 St. Irenaeus (Adversus haereses, 1.26.3) and St Hyppolitus (Refutation of All Heresies, 7.24) argue that the name of this heretical group comes from the deacon Nikolaos, one of the seven (Acts 6.5). St Irenaeus says that the Fourth Gospel was written to answer the heresies of the Nicolaitans (Adversus haereses, 3.11.1). Another tradition defends deacon Nikolaos against the charges of immorality. See: Clement of Alexandria (Stromata, 3.25.5-26.3) and Eusebius of Caesarea (Church History, 3.29.2-4).

23 For the interpretation which follows see more in: Gregory K. Beale, The Book of Revelation. A Commentary on the Greek Text, The New International Greek Testament Commentary, Michigan, Grand Rapids, Cambridge, U.K., Eerdmans, Carlisle, The Paternoster Press 1999 , p. 230-232. 
6.3 Good works come from Christ. The Church in Laodicea offers a striking example of works devoid of substance. Apparently, this Church has a lot of good things. What Christ says about its wealth and lack of need covers most probably not only material things, but also what generally people can call 'good works' for which the community was proud of, as the parallelism between 3.17a and 3.17b-18 points out. Similarly, the Church in Sardis seems to be renowned for its works. Apparently, due to these works it owes its good name among the Churches. Given this reality, the verdict of Christ is shocking. "You are dead," ${ }^{24} \mathrm{He}$ says to the one which seemingly is known for its vivacity (3.1). Surprisingly the problems come exactly from the works: "I have not found your works perfect before God" (3.2). Notice that the text does not say that there are no works, but that these works are not perfect $(\pi \varepsilon \pi \lambda \eta \rho \omega \mu \varepsilon \dot{v} \alpha)$. The full meaning of the affirmation is enigmatic, but the context offers us a good clue. Fortunately not all the members of the community are in this situation. Few of them "have not defiled their garments" (3.4a). With their white garments they are and will be ${ }^{25}$ with Christ (3.4b). That means that all the other members of this Church have defiled their garments. And this brings the first answer: their works are not perfect because their deeds include the defilement of the garments, an image which suggest the presence of un-repented sins in their lives.

Such a clue is present, but not so evident, in the message to the Church in Laodicea: its nakedness can be covered only on the condition of "buying" from Christ "white garments". Moreover, Christ offers to this Church also "gold" and "eye salve" (3.18). The price is stated in the next verse: "Be zeal-

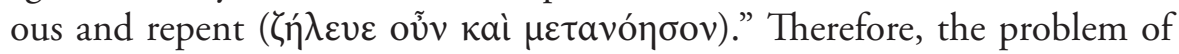
this Church is not only its "poverty" and "nakedness", but the incapacity of seeing where it really is, and this blindness is generated by lack of zeal, which is closely related to the lack of love and to the lack of repentance. Thus, our text stresses both Christ's active work and the sine qua non human action. Only when the divine action meets adequate response the "gold", "white garments" and "eye salve" have positive meaning for humans. The works which matter are not 'bumper stickers' on Christians. They are intimately related to what they are in Christ. Their source is Christ and His grace. The

24 However, the following verse (3.2) shows us that the adjective "dead" (veкpóc) must be understood as a hyperbola, which has the function to point out the precarious spiritual status of this community and the imminent danger of ultimate death. G. Beale, The Book of Revelation, p. 273.

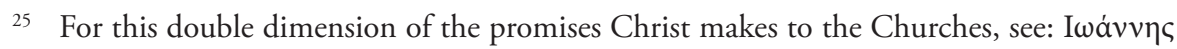

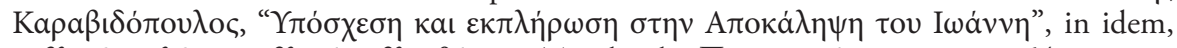

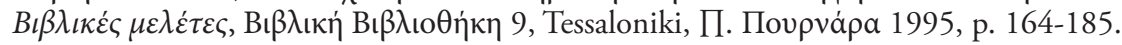


"gold" belongs to Him and only in communion with Him can be enjoyed and communicated to the others. In other words, Christ is pointing out here exactly the same thing as in the Fourth Gospel: "He who abides in Me, and I in him, bears much fruit; for without Me you can do nothing" (John 15.5).

The twenty-four elders, who represent God's people, put their golden-crowns down before the throne acknowledging that their victory belongs to the Lord (4.10). As in the previous chapters the victory is closely related to the works; this image again points out Christ as the ultimate author of them. This echoes Phil. 2.12-13, where St Paul exhorts his followers to "work out with fear and trembling" their own salvation (Phil. 2.12), having always in

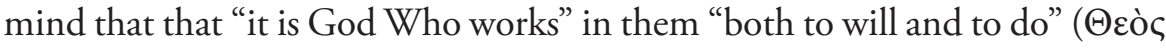

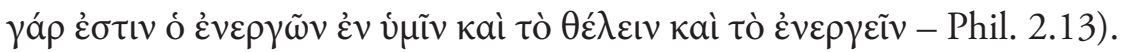

\section{Conclusions}

St John's Revelation provides a solid ground for a better understanding of what salvation really means. The salvific work of Christ is not only the very core of history, but also the fundament and continuous source of Christian life. Therefore there is no real Christian life but only in close communion with Him. The authentic faithful know that everything they are and have come from Him and for that they praise Him incessantly. In fact their status requires continuous worship. By washing their garments in the blood of the Lamb, they have become priest of God and partakers of His Kingdom. That's why their entire existence is evolving in His presence and implies continuous dedication to Christ as their Redeemer. Their priestly model is Jesus Himself, Who has shown us what faith means. This kind of faith must be the fundament and source of every Christian work. Therefore faith constitutes the precondition of all good works. But the works themselves do not have only demonstrative value of the faith. The book points out a kind of synergy between these two. Encountering Christ, humans can enter into communion with Him by means of a series of active actions. Repentance, washing, keeping Christ's word, the service of priesthood, all these mean works. There is no other way to fulfill the Christian calling than by works.

The fulfilment of God's plan of salvation depends on the active participation of humans. The deeds of the Christians must have a missionary relevance since only through them the Gospel is brought to the margins of the earth. The image of conquest points out the value of acting for salvation, as does the repeated warning that everyone will be judged according to his/ her works. By means of the works (proclamation of the Gospel) the faithful is called to Christ, by means of the works (the effort of understanding and receiving the Good News) he/she encounters Him and decides to leave 
the ungodly life in order to live in communion with Him, and by means of the works (accomplishment of the commandments) one also remains in communion with the Lord and enjoys the goods of the Kingdom, from which the consecration to priesthood is the greatest because it allows him to stand continuously before the throne of God and to worship Him. Thus the 'work' imagery plays a crucial role in the theology of the Apocalypse; without works them neither the encounter with Christ, nor abiding in communion with Him is possible ${ }^{26}$. But they are also the expression of this abiding, since whatever good fruit the Christians produce is first a gift coming from Christ, as the metaphors of gold he is offering to the Church suggest. In other words, the Apocalypse does not contradict the Pauline teaching, but rather illustrates it through its complex 'works' imagery. In the works of the faithful God is at work (cf. Phil. 2.13).

The book of Revelation stresses that salvation implies a progress in which the works play a crucial role. Keeping the 'whiteness of the robes' requires love, zeal, attitude and action according to God's will. All these have soteriological, ecclesiological, historical and cosmological significance. The wedding of the lamb will take place only when the "robe" of the Bride will be ready. Or, this is made by the righteous deeds of the saints (19.7-9).

Probably the best explanation of the complex relationship between God's will, Christ's work, grace and human action and its relevance for the salvation was formulated in the seventh century by St Maxim the Confessor († 662). In the Apocalypse, Christ points out that the final goal of the whole salvation work is the divinization of the humans. That is what the sitting on God's throne means (3.21). St Maxim stresses that the divinization is the gift of God and that it cannot be realized but by Him. Humans cannot work out the divinization themselves. Therefore the works do not save by themselves but show the openness to the grace and the receptivity of it. But the openness and the receptivity do correspond to the measure of self-abandonment and communion with $\mathrm{God}^{27}$. The works are expressing exactly that measure.

\footnotetext{
26 Pierre Prigent sees in these two mysteries (the encounter and the communion) exactly the main point of the Apocalypse: "This is the most profound message of the book of Revelation: it is in the encounter and communion with Christ that the destiny of mankind is played out." Pierre Prigent, Commentary on the Apocalypse of St. John, Tübingen, Mohr Siebeck 2001, p. 640.

27 Jean-Claude Larchet, La divinisation de l'homme selon saint Maxime le Confesseur, Paris, Cerf 1996, p. 647.
} 